\section{Aktivitetshåndboken - hva forventer myndighetene å oppnå med den?}

Det var med vantro jeg nylig mottok Aktivitetshåndboken på hele 621 sider i «gave» fra Helsedirektoratet (1). Hva tror helsemyndighetene de kan oppnå med å forære denne boken til alle landets fastleger, kommuneleger og bedriftshelsetjenester? Har de tatt seg bryet med å spørre mottakerne om de føler behov for den og om de kommer til å anvende disse utrolig detaljfokuserte opplysningene for å få pasientene til å øke sin fysiske aktivitet? Jeg tror svaret hadde blitt: Nei! Boken vil bli nok en støvsamler i bokhyllen hos de aller fleste kolleger. I miljøkampens navn burde man i det minste klart seg med å legge ut innholdet på Internett og meddelt dette til interesserte leger på et lite postkort.

Boken er etter mitt syn like virkelighetsfjern som Grønn resept var/er. Den bærer preg av å være redigert og skrevet av mennesker som ikke har noen anelse om hva vi fastleger kan ha nytte av i vårt daglige arbeid for å øke befolkingens grad av fysisk aktivitet. Det vrimler av professorer og sykehusspesialister blant forfatterne, men jeg fant ikke en eneste allmennlege! Når skal det bli slutt på å bli belært av kolleger med fine titler uten den ringeste innsikt i hvordan vår hverdag er konstruert?

Etter mitt syn burde boken blitt kortet ned til to setninger (som det da er plass til på ovennevnte postkort): Første setning bør handle om pasientene: Tilpasset fysisk aktivitet er nyttig (nesten) uansett hvilken lidelse de måtte ha. Den andre setningen er til myndighetene: For å øke graden av fysisk aktivitet $\mathrm{i}$ befolkningen trengs det midler og konkrete opplegg som kan gjennomføres i nærmiljøet. Lag takster tilpasset trening i grupper eller la primærhelsetjenesten benytte de samme takstene som helseforetakenes lærings- og mestringssentre. Størst mulig helsegevinst hos flertallet av våre pasienter (de med overvekt, diabetes, hypertoni) oppnås ved å ha to tanker i hodet på en gang: Kombinert kostholdsundervisning og treningstilbud gir mye bedre resultater enn bare å være opptatt av en ting om gangen. Dette temmelig opplagte forholdet har ikke fătt noe fokus i boken - hvor er helhetstenkningen?

Hvor mye penger har man brukt til dette bokprosjektet? (Jeg imøteser et tall!). Tenk om disse midlene hadde blitt brukt mer kreativt! Man kunne lagt en kortere, mer allmennpraksisnær versjon ut på nettet $\mathrm{og}$ så brukt resten av midlene (og helst mye mer!) til å utlyse en konkurranse om hvem som kan lage de beste prosjektene for å få til økt fysisk aktivitet på grasrotnivå i sin kommune. I etterkant kunne man så evaluert hvilke prosjekter som ga mest uttelling per krone og jobbet videre derfra for å tilrettelegge for økt fysisk aktivitet $\mathrm{i}$ befolkingen.

\section{Jannike Reymert}

Namsos

\section{Litteratur}

1. Aktivitetshåndboken - fysisk aktivitet i forebygging og behandling. Oslo: Helsedirektoratet, 2009 